\title{
Econometric Analysis of Tourist Demand in the Absheron Peninsula (Baku-Azerbaijan)
}

\author{
Gadir Bayramli $^{1} \&$ Vasif Aliyev ${ }^{1}$ \\ ${ }^{1}$ Department of Economics and Business Administration, Azerbaijan State University of Economics (UNEC), Baku, \\ Azerbaijan
}

Correspondence: Assoc. Prof. Gadir Bayramli, Department of Economics and Business Administration, Azerbaijan State University of Economics (UNEC), Baku, Azerbaijan. E-mail: kadirbayramli@gmail.com

Received: April 27, 2020

Accepted: June 14, 2020

Online Published: June 18, 2020

doi:10.5430/rwe.v11n3p251

URL: https://doi.org/10.5430/rwe.v11n3p251

\begin{abstract}
In today's modern world, tourism has become an ascendant business, withal one of the most remuneratively lucrative and dynamic sectors of the economy. The tourism business is correspondingly developing on the Absheron Peninsula (Baku-Azerbaijan), where the development strategy is mainly conducted by the state. Since tourism has an impact on the development of the territory: it avails to replenish the budget, ameliorate convivial and market infrastructure, engender incipient jobs and contributes to the development of employment, the main directions of state measures for the development of the tourism industry of the Absheron Peninsula are withal identified. Since the tourism industry is developing on the Absheron Peninsula (Baku-Azerbaijan), it is suggested to develop new tours and routes, ways to expand cooperation with leading universities of the world in order to develop exchange of experience. The article discusses the historical development of tourism on the Absheron Peninsula (Baku- Azerbaijan). The definition of the rudimental concepts of the tourism industry on the peninsula is provided, the socio-economic factors in this area are deemed. Since the economic factor plays a paramount role in the development of this area, the key development areas are identified. The research results can be applied in the further development of the Absheron Peninsula tourism business (Baku-Azerbaijan). The study is predicated on an analysis of literary and statistical sources. The fundamental data in the research process were designators of the tourism industry in Azerbaijan. The assessment of the prospects of tourism development on the Absheron Peninsula (Baku-Azerbaijan) is presented. Thereafter, the estimation methodology is discussed with a presentation of the univariate characteristics of the data. Determinately, the estimation results are discussed and conclusions are drawn from the findings. The consequentiality of the financial component of scholastic tours that require certain investments is indicated. In the process of research, quandaries were identified along with their solutions.
\end{abstract}

Keywords: tourism, tourism resources, tourism development, tourism industry, tourism institution

\section{Introduction}

Modern world is experiencing robust growth in tourism sector and this improvement is expected to continue. Categorically developing countries consider tourism as a sector that could potentially cover their desiderata in foreign currency. Tourism has a paramount role in the socio-economic development of the region of the Absheron Peninsula (Baku - Azerbaijan). Fulfilling tourism's potential as an engine for sustainable and inclusive growth will require the development of sound policies, integrated strategies, inter-ministerial structures, and mechanisms that involve the private sector and other stakeholders in tourism governance. The contribution of the tourist sector is benign for a country's economy due to its influence on sectors other than the peregrine exchange sector. Medical tourism is prosperously developing in the area, since the climatic features of the peninsula are highly felicitous for the intensive development of resort and tourist activities.

The current United Nations development program for countries with developing tourism serves as a powerful tool for socio-economic development, cultural heritage conservation and biological development activities. Tourism activities on the peninsula have a positive impact on solving the key socio-economic issues that are appertaining to this region. Thus, tourism has contributed to the formation of:

- new jobs in the region; 
- the elimination of the flow of people to the city from the most proximate villages;

- the growth of communications;

- the growth of cultural ties between the population of the peninsula.

The main focus of the study in the article is the health resort treatment in the region, which is the substructure of the tourism business of the Absheron Peninsula (Baku - Azerbaijan).

The purport of the work is to assess the level of potential for the development of tourism business on the Absheron Peninsula (Baku - Azerbaijan) (Balayev, 2019).

The development of non-petroleum sectors is of great significance for Azerbaijan, whose foreign sales are highly dependent on crude oil and petroleum products. Among the non-petroleum sectors, tourism is considered as one of the leading areas and attention to tourism is incrementing. Absheron region, which possesses a paramount part of tourism resources, has a more propitious position in terms of economic potential, transportation, qualified staff and the evaluation of tourism resources. The fact that the capital Baku is located in this region, the region is situated on the sea shore, and it has modern transportation terminals, has an important part in the development of tourism activities. In recent years, the organization of the 1st European Olympic Games, Islamic Solidarity Olympiad, Eurovision Song Contest and other international events in Baku have contributed to the development of tourism, enabling millions of people to meet Azerbaijan's tourism opportunities, particularly the capital Baku. The predominance of economic and political stability in the country and the implementation of State programs on tourism development encourage the expansion of tourism activities. Advances in the field of tourism education and the works carried out in the field of promotion have brought an incipient speed to tourism and incremented the tourist influx into the country (Gandilova, 2018). Despite many successes in the Absheron region, which is considered as the main tourism center of the country, there are some problems in the field of tourism, and the detection and solution of these problems can transform the region into an active tourism destination.

The Absheron region, consisting of the cities of Baku and Sumgayit, the Absheron and the Hizi districts, is the most developed region of Azerbaijan and is distinguished by the intensity of economic activities. The fact that the region, including the capital city of Baku, is located on the Caspian coast provides consequential advantages to the region. Industrial activities in Absheron, which is one of the first regions where oil is extracted in the world, still maintains its significance today. In addition, Absheron is the most developed tourism region of Azerbaijan. The warm sea, wide sandy beaches, mild climate and rich historical-cultural resources show that the region has a great potential in terms of developing tourism (Rassokhina et al. 2015). Appropriate geographical location and dense transportation network are considered as important factors in the development of tourism activities. In the regional development programs and the Strategic Road Map for Tourism, the Absheron region is among the leading regions. The development of regional tourism requires scientific research and multi-faceted analysis of tourism activities. In this article, the natural and historical-cultural tourism resources of Absheron region are evaluated, the current situation of tourism is addressed, problems are identified and solutions are presented. The article has focused on statistics, regional analysis, comparison and cartographic methods.

\section{Research Methods}

Research methods, such as analysis of economic and regional literature, general research means, theoretical and epic methods of scientific knowledge, were used when writing the work. The principal method used in the paper is the internal selective economic analysis method. Methods of a systematic approach, comparative and economic analysis, statistical groupings, as well as selective statistical studies were also applied. To determine the market concentration, the coverage coefficient of the tourism industry in the region was calculated. Also the calculated Herfindahl-Hirschman Index is defined as the sum of the squares of the shares of all firms operating in the market.

\section{Literature Review}

To conduct this study, relevant and authoritative sources were used. The author assesses the current state and prospects of tourism development in the Republic of Azerbaijan. The economic and social geography of the Republic of Azerbaijan was analyzed. Sources that reveal the main directions of the implementation of investment projects of tourist and recreational clusters are examined. Government spending in support of general tourism activity can include national as well as regional and local government spending. For example, it includes tourism promotion, visitor information services, administrative and other public services. The development prospects of the industry are reflected in "Azerbaijan 2020: Look into the future" Development Concept. 
Ahmadov and Mammadov (2015) studied the current situation of the tourism sector, which pursues oil industry for its significance in Azerbaijan industry. His studies are aimed at evaluating the current situation of the tourism sector in Azerbaijan and making suggestions to improve the competitiveness. Additionally, the potential significance of the macroeconomics of the country was studied.

Mirzayeva et al. (2020) the results of the study showed that in addition to the "development of tourism infrastructure", other positive aspects (infrastructure development, protection of natural resources and cultural heritage) of environmental impact and only the "positive measurement of social security" of social impact had a significant positive impact on the sustainability of cities.

\section{Natural Tourism Resources}

The natural conditions and resources of the Absheron region provide important opportunities for the development of tourism. Warm climate and sea, sandy beaches, healing waters, mud volcanoes are prerequisites for the development of tourism.

Climate. The temperature of the air, the high sunshine hours (2244 hours per year) enable the temperature throughout the year to be above $0^{\circ}$. The average annual temperature of the air varies between $+13.5-14.4^{\circ} \mathrm{C}$. In the summer season, the middling temperature will be above $20^{\circ} \mathrm{C}$. The average temperature for July ranges from $+24.7 \mathrm{C}$ (in the north) to $+25.6^{\circ} \mathrm{C}$ (in the east). The figures for January vary between +2.9 and $+3.8^{\circ} \mathrm{C}$. The number of days above $0^{\circ} \mathrm{C}$ is 268-293 days. The amount of rain is $500 \mathrm{~mm}$ in the north-west and decreases to $150 \mathrm{~mm}$ in the south. (Soltanova, 2015). Low amount of rain and sparse river network cause poor development of vegetation. Frequent blowing "Khazri" (North) winds cause the temperature to go down $8-10^{\circ}$ in winter. The aforementioned winds prevent overwhelming temperatures in the summer. The temperature of the sea water reaches $17^{\circ} \mathrm{C}$ in the middle of May around Baku and this temperature is considered enough to go into the sea. The temperature reaches $20^{\circ}$ in June and $23-25^{\circ} \mathrm{C}$ in August and therefore summer months constitute the period when beaches are used most intensively. Despite the decrease in temperature, it is possible to go into the water in the first ten days of November. Thus, the beach season in the Absheron region covers a period of 5-5.5 months. The annual average indicator of relative humidity in the Absheron peninsula is $65-70 \%$. The number of cloudy days is around 115 . This factor affects tourism activities positively (https://www.gks.ru free (date accessed 02.02.2020).

Beaches: The characteristics of the beaches in the Absheron region is that it shows an alteration from north to south. Sumgayit and Novkhani beaches in the north of the region are sandy and the underwater slope is low. This makes it easier for children to swim. Pirshagi and Buzovna beaches have similar features to Novkhani beach. But soil is contaminated and high waves caused by the winds make it difficult to swim in the Northern Absheron beaches. It is also an undeniable fact that the beaches around Nargin and Pirallahi are stony and rocky and high waves limit the use of the beaches.

The beaches between Turkan and Zira are wider. Shikhov beach located in the south of the region is among the most used ones. But as a result of industrial activities, the rate of soil contamination is quite above the norms. Carrying out unplanned tourism activities on beaches and their surroundings lately; fencing beaches, transporting sand as a construction material affects beach tourism negatively.

Healing Waters. There are waters that have some healing importance in Absheron, Surakhan (flow rate 510 thousand 1 / day), Buzovna ( 80 thousand 1 / day), Bilgah (280 thousand 1 / day),

The waters of Mardakan (620 thousand 1 / day), Buzovna (80 thousand 1 / day), Pirshagi (35 thousand $1 /$ day), Shikhov (150 thousand $1 /$ day) are considered to have more perspective (http://eco.gov.az) In addition, iodized-brominated waters in Bina and Hovsan can contribute to the development of medical tourism.

Mud volcanoes. There are over 300 mud volcanoes in the country (almost all of them are on the Absheron peninsula and its surroundings) and it constitutes more than one third of the world mud volcanoes. Mud volcanoes can play an important role in organizing medical tourism as well as ecotourism. Treatment centers can be established near the volcanoes. It is known that mud volcanoes are used in nerve, herniated disc, joint and skin diseases in many countries of the world. As a result of the cooperation with related bodies, the use of mud volcanoes for medical purposes may be beneficial in increasing the influx of tourists into the country (Abdullayeva, 2011).

\section{Historical-Cultural Resources}

The coastlines of Caspian Sea, especially Absheron region, is rich with cultural as well as historical attractions. There is Ateshgah, which is the symbol of Zoroastrianism and the temple of the worshipers, in $30 \mathrm{~km}$ far away from Baku. Next to the temple, there is a museum which narrates the life of the people who worshiped the fire and the 
temple. 44 monuments belonging to the XII century is located in an area of 22 hectares within the walls of Icharishahar. Shirvanshahlar palace (XV century), Siniggala Minaret (XI century), Maiden Tower (XII century), and the minaret of the Juma Mosque (XV century) are more visited out of them. Shirvanshahlar Palace which is composed of the Divankhana, Shah Masjid, Key Gubad Mosque, the shrine of the famous astronomer Yahya Bakuvi, Murad's Gate, Shirvanşahlar Mausoleum, bathhouse and water reservoir were built by the order of Shirvan ruler I Halilullah and his son Ferruh Yasar in the 15th century (Mammadov, 2002).

Mosque-Madrassa (14th century), Haji Bani Mosque (16th century), Multani (12-14 centuries) and Bukhara caravanserais (15th century), Agha Mikayıl Bathhouse (18th century) are known as important historical monuments.

Among other important historical-cultural wealth of Baku are Azerbaijani and Turkish Martyrs, Mosques, Ismailiyya Palace, Azerbaijan History Museum, Nizami Museum of Literature, Saadat Palace, Azerbaijan State Philharmonic Hall, Museum of Fine Arts, monuments and home museums of many artists and writers. The buildings made by the oil rich until 1920 are considered as works of art, and the contemporary architectural structures built during the Soviet and Independence Period also have an important place.

In the Gobustan region, $70 \mathrm{~km}$ south of Baku, there are over 10 thousand rock paintings, caves where ancient people had lived, and old cemeteries. The region has been taken under conservation and some measures have been taken for its promotion. As a result of the research studies carried out since 1947, approximately 6000 human and animal pictures were revealed on approximately 1000 rocks and various signs and stamps and containers used to collect rainwater and blood of sacrificial animals were discovered here. (Ministry of Culture and Tourism of the Republic of Azerbaijan, (MCTRA, 2014)).

\section{Current Status of Tourism}

Considering its natural environment, climate suitability for retreatment, warm and clear sea, fine sandy beaches, mud and healing waters used for medical purposes, transportation and infrastructure development, it is one of the most important regions in the country where recreational retreatment complexes can be built. As a matter of fact, most of the therapeutic sanatoriums in Azerbaijan are here. Namely, there are many major recreational centers specialized in cardiovascular, nervous system, gastrointestinal diseases (Huseynov, 2003).

On the other hand, this peninsula is a camping center where the busiest child-youth parks of Azerbaijan are found. In recent years, initiatives have been made to improve the wellness resorts here and to establish new ones. In the thermal tourism of the Absheron Peninsula; Hydrogen sulfide water sources are of great importance in Surakhani, Shikhov, Bilgah, Buzovna, Pirshaghi and Mardakan.

Moreover, Baku, the country's largest city, is located in here. This is one of the advantages of the Absheron region. The 1st European Games, the $4^{\text {th }}$ Islamic Solidarity Games, Eurovision Song Contest, Formula 1 races and other international events hosted by Baku show the importance of the region in terms of tourism. The new infrastructure built here will be even more important in the future. International events are very consequential for the promotion of the country, especially for the promotion of the city of Baku. 78 artificial islands will be constructed and 150 bridges connecting these islands will be built on the shores of the Caspian Sea, the capital of Baku. The construction of lavish and shapely islands, which is important for tourism, is expected to be completed in 2023 on the Caspian Sea.

Mega-events have different types of effects for host cities or countries. The impact indicators of the Formula 1 Grand Prix in Baku, Azerbaijan from the perspective of tourism stakeholders and to investigate the effects of these impacts on the urban sustainability through the perceptions of stakeholders after the Formula 1 Grand Prix. The results indicated that environmental and social impacts exerted significant positive effects on urban sustainability. (Mirzayeva, G. 2020)

Health tourism is one of the categories of tourism that needs to be developed in Absheron. "Ganjlik", International Tourism Center, "Neptun" tourist base and sanatorium-holiday centers (Bilgah, Mardakan, Buzovna) operate in the region with a balneological climate. The salty lake, mud and oil used for medical purposes in Novkhani are also among the remarkable features of health tourism in this region. Numerous health sanatoriums have been operating in Absheron since the Soviet era, and new ones have been added to them today and the older establishments have been restored. As can be seen, Absheron, which is a region rich in oil and natural gas on the Caspian coast, also gives positive future promises to the economy of Azerbaijan with its tourism potential. A special importance was attached to the Absheron region in the State Programs on Tourism Development and the "Strategic Road Map for the Development of Tourism Industry", formed in 2016, and concrete procedures regarding the use of the tourism potential of the region were listed. 


\section{The History of Development}

The territory of the Absheron Peninsula (Baku - Azerbaijan) has long been one of the most visited places in the world. Here people assemble from different parts of the world. In 1908, a branch of the Crimean Caucasus Mountain Club was opened in Baku (Donskova, 2018). It was during the period that the intensive development of tourism activities in the region commenced. Since 1910, tourist trips to the Caucasus have been organized, which have become a key aspect in the formation of tourism on the territory of the Absheron Peninsula (Baku - Azerbaijan). In the Soviet period, the Absheron Peninsula (Baku and surrounding areas) was the locomotive of tourism in Azerbaijan. The main tourist industry was created here and most of the domestic and international tourists visited the Absheron region after Independence was gained in 1991.

Recent years have seen a growing recognition of the importance of the development, management and promotion of local destinations, supported by regional or local structures and funding, and the preparation and execution of destination management plans. A wide range of steps have been taken to develop and market distinctive products and destinations. Marketing activities have included various examples of successful regional and thematic branding. Many countries have made new offers and experiences based on their natural and cultural assets, and pursued opportunities for year-round growth through the promotion of health and wellness tourism, business tourism, events and various niche products. Tourism policies continue to give a high priority to opportunities presented by digitalization both in creative and targeted communication and in conduct and analysis of data. A marked improvement with the inclusion of fixed effects suggests that most of the heterogeneity can be explained by destination features which stay the same or vary very little over time. Adding spatial effects to the panel data models also increases forecasting accuracy, the improvement is small, though. The spatial distribution of spillover effects is drawn on a map and a spatial pattern is recognized. Azerbaijan has begun to develop the tourism industry. Reforms have been carried out and government programs for tourism development have been prepared. Absheron region has retained its leadership and created a modern tourism industry.

\section{Modern Development Trends}

Today, the region is mainly visited by men. Statistics of visits are shown in Figure 1.

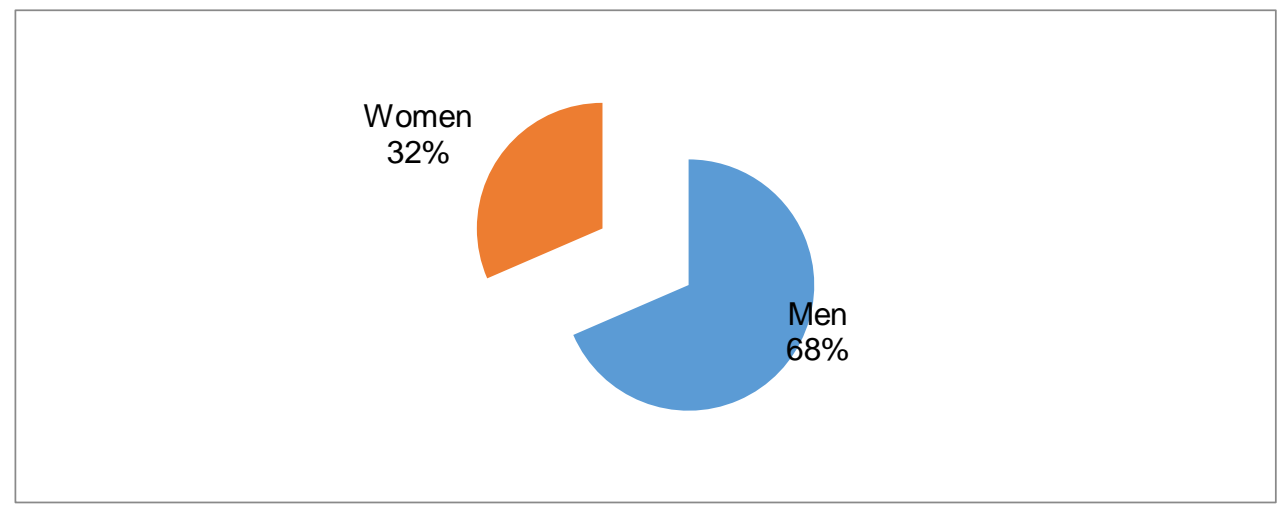

Figure 1. Statistics of visits to tourists by gender (Source: Author's own)

Thus, it can be emphasized that the majority of visitors to the peninsula are men. Visitor statistics for tourists from different countries are shown in Figure 2. 


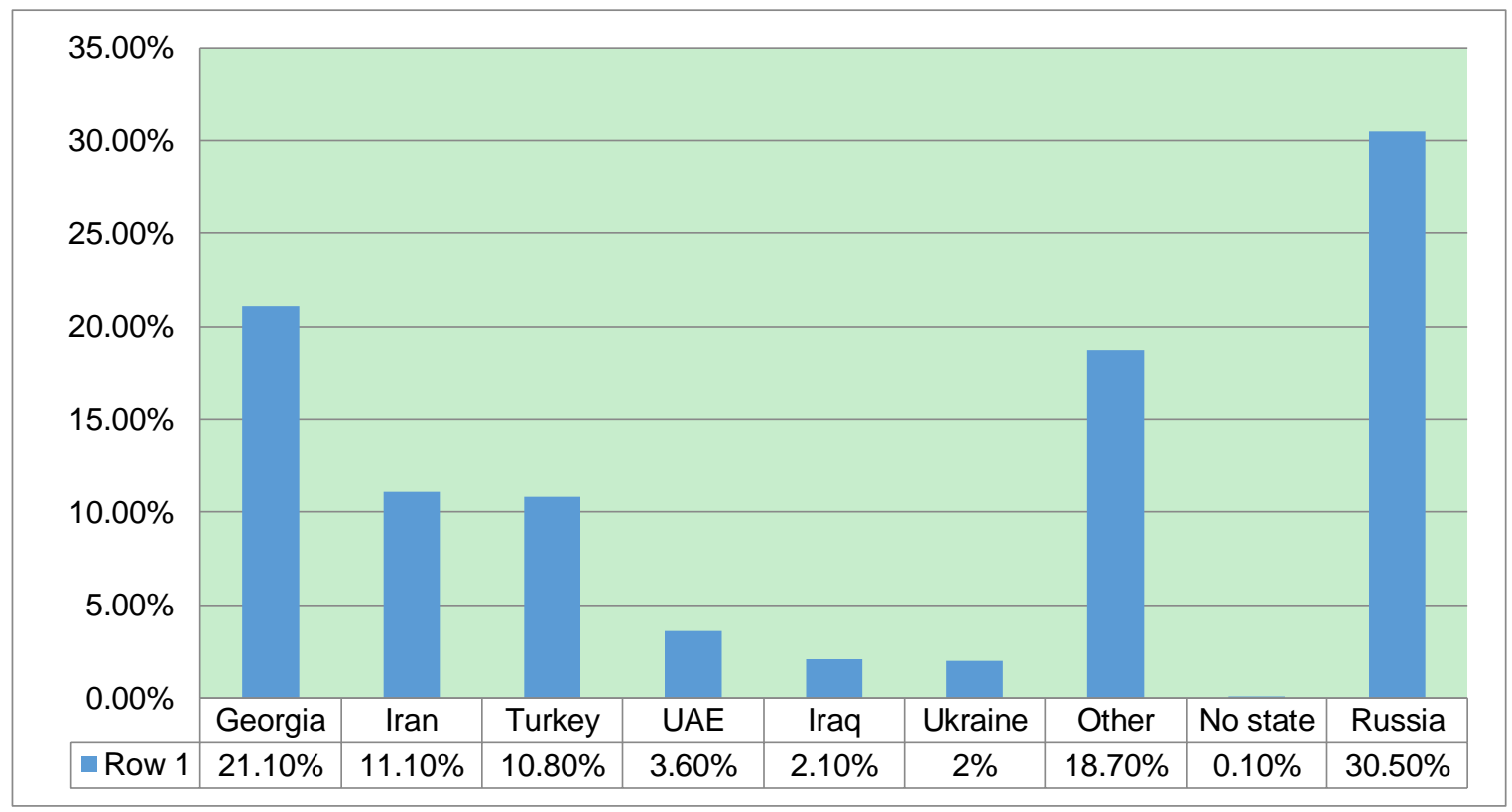

Figure 2. Statistics of visits to the Absheron Peninsula

It should be noted that the main visitors of the Absheron Peninsula (Baku - Azerbaijan) are Russian citizens. The Absheron Peninsula continues to hold the top tourist ratings from Russia. In 2019, 53.5 thousand Europeans visited the peninsula. The number of tourists from the CIS countries amounted to 478.3 thousand people. Statistical data has shown an upward trend. The growth of tourists from China is 5.1 times more compared to the analogous period of 2018. The tourist percentages for Saudi Arabia, Bahrain, Qatar, Oman were 3.5 times, 2.6 times, 2.1 times and 1.6 times more than in the same period last year respectively. It must be emphasized that the increase among tourists from Iraq amounted to $44.3 \%$ and from the UAE to $8.8 \%$. The main factors of tourism development. (URL: http://tourfaq.net/travel-bissnes/glavnye-faktory-vliyayshhie-na-razvitie-turizma/:accessed 02.02.2020).

Currently, the share of tourism in GDP on the peninsula is about 2\% (Tourism in Azerbaijan. URL: http://azerbaigan.tourism.az/ ru/peges/ 17: accessed 02.02.2020). Over the past ten years, the number of exported and imported tourism services has increased, the rate of which has increased by an average of $30 \%$.

The state is actively working on the formation of regulatory legal acts. Acts contribute to the promotion of relations and favorable conditions for investments:

- assisting the advancement of services in the domestic and global market;

- the formation of conditions for the protection of the rights, security and conditions of

stay in the territory of tourists;

- licensing and standardization of tourism activities and more (Tourism in Azerbaijan, 02.02.2020).

As part of the development of tourism, a tourism development program is being implemented until the end of 2020, "Azerbaijan - 2020: Look into the future." This project aims to develop infrastructure in the tourism sector, the formation of measures to develop tourism potential on the peninsula, and more. Tourism can affect the demand for certain services such as transportation. For air transport, which is usually the largest component of international tourism spending, tourists are affected by the routes that can be used, the airlines available to fly specific routes, the number of flights available, the number of seats on routes as well as the prices that are charged. (The concept of development "Azerbaijan - 2020: Look into the future." 02.02.2020).

The main posed problems today are:

- the high cost of hotel accommodation, food, transport and other services;

- lack of ready-made investment sites for investing in tourism activities;

- macroeconomic risks. 
In order to develop tourism activities on the territory of the peninsula, major sanatoriums are being reconstructed, thoroughly repaired, put into operation and safely accept a large flow of tourists.

\section{Theoretical and Practical Research Results}

The empirical results on long-run estimates reveal that the income level of a country's tourism basket, across all quantiles, plays an important role in accelerating economic development. The findings from all these quantiles are statistically significant at either a $1 \%$ or $5 \%$ significance level. Similarly, capital positively drives economic performance and the coefficients for all quantiles are statistically significant at the $1 \%$ level. Although non-renewable energy consumption, renewable energy consumption and labor positively contribute to the economic performance in all quantiles, their coefficients are not statistically significant in every quantile. However, the effects of all explanatory variables for the 10th quantile are statistically significant at least at the 5\% level. To determine the market concentration, the coverage ratio of the tourism industry in the region was calculated (formula 1).

$$
\text { Crat }=\text { CSVP/SSVP } * 100 \% \text {; }
$$

CSVP-sales volume of company services for the period (month, year, quarter);

SSVP - sales volume of state services for the period (month, year, quarter).

Table 1. Indicators of coverage rate in the tourism industry $\%$

\begin{tabular}{lcccc}
\hline Year & 2016 & & 2017 & 2018 \\
\\
\hline Coverage ratio & & 86,18 & 89,44 & 90,97 \\
\hline
\end{tabular}

Source: Tourism in Azerbaijan. URL: http://azerbaigan.tourism.az/ ru/peges/ 17: accessed 02.02.2020

Thus, the coefficient increased by 5.56\% in the period of 2016-2018. In 2018, the ratio was $90.97 \%$. These indicators show the effective development of tourism activities on the Absheron Peninsula (Baku - Azerbaijan). Next, the tourism market concentration index was calculated (The main factors of tourism development, 02.02.2020).

The market concentration index was calculated by the formula (2):

$$
C R_{k}=\sum_{i=1}^{k} y_{i}, k \leq N
$$

where

$\mathrm{CR}_{\mathrm{k}}$ - concentration index;

$\mathrm{N}$ - the number of firms in the industry;

$\mathrm{y}_{\mathrm{i}}$ - service sales share;

$\mathrm{i}$ - the company in the total output (sales) of the industry.

Table 2. Market concentration index criteria, $\%$

\begin{tabular}{llll}
\hline Year & 2015 & 2016 & 2017 \\
\hline Concentration index & 58,64 & 66,20 & 65,32 \\
\hline
\end{tabular}

Source: Tourism in Azerbaijan. URL: http://azerbaigan.tourism.az/ ru/peges/ 17: accessed 02.02.2020

There are following concentration index criteria:

- the industry is not concentrated (below 45\%);

- the industry is moderately concentrated (45-70\%)

The demand for tourism would follow the supply of cheaper transport if the cost of transport could be significantly reduced through new economies of scale or through some technological, cost-saving breakthrough. The price of crude oil can also severely affect the tourism industry and there is little doubt that with increasing fuel prices 
disposable incomes are likely to shrink through fuel-price induced inflation. To obtain a complete description of the tourism market, the Herfindahl-Hirschman index was calculated.

The Herfindahl-Hirschman index is defined as the sum of the squares of the shares of all firms operating in the market:

where $\mathrm{HHI}$ is the Herfindahl-Hirschman index;

$$
\mathrm{HHI}=\sum_{i=1}^{N} y_{i^{2}}
$$

$\mathrm{y}_{\mathrm{i}}$ - share of production (sales of services)

$\mathrm{i}$ - the company in the total output (sales) of the industry;

$\mathrm{N}$ - the number of firms in the industry.

Table 3. Indicators of the Herfindahl-Hirschman index

\begin{tabular}{llll}
\hline Year & 2016 & 2017 & 2018 \\
\hline Herfindahl-Hirschman index & 1630,1 & 1950,43 & 1857,19 \\
\hline Source: Tourism in Azerbaijan. URL: http://azerbaigan.tourism.az/ ru/peges/ 17: Accessed 02.02.2020 &
\end{tabular}

Source: Tourism in Azerbaijan. URL: http://azerbaigan.tourism.az/ ru/peges/ 17: Accessed 02.02.2020

The index value is normative from 100 to 10,000 . This growth does not only showcase the sector's resilience and capacity to bounce back from security shocks, but also its ability to spread its benefits widely across the world. Thus, in the study period, the market for tourism on the peninsula has been considered oligopolistic, since according to the calculated index, a value close to 2000 is oligopolistic. It can be stated that in the future there will be a trend towards further monopolization of tourism activities due to the acquisition of some economic entities. Today, five-star hotels are located on the territory, which are fully capable of meeting the needs of tourists by providing luxury service. It should also be noted that tourists prefer 3-4 star hotels. Analytics is used by traveler-focused businesses worldwide to monitor and anticipate traveler arrivals from a particular origin market at a concrete time. The way of attracting tourists to the peninsula is also the international festival in Baku, which contributes to a large influx of tourists into the country. Advertising and publicizing activities are actively functioning in the territory, within the framework of information on the peninsula tour which began to be presented on board of the aircraft of the national aviation company, information was provided for international tour operators and tourist exhibitions, and information centers were opened. This analysis enables parties to anticipate the impact of events, better manage their staffing levels, fine tune supply requirements, adjust and measure the effectiveness of their marketing efforts and anticipate future market trends.

\section{Main Tourism Problems and Solution Suggestions}

A high majority of countries have devised their tourism policies, strategies and plans from the medium to long-term. There are many similarities in countries' tourism policy priorities, which focus on improving competitiveness, sustainability and inclusiveness, addressing seasonality of demand, and enhancing the quality and appeal of the tourism offer. The tourism problems of the Absheron region are mainly related to the lack of infrastructure, staffing, publicity, and poor tourism awareness. Sustainable development of the tourism sector will depend on its ability to adapt to emerging economic, social, political, environmental and technological trends. Fulfilling tourism's potential as an engine for sustained and inclusive growth will require the development of sound tourism policies, integrated strategies, inter-ministerial structures, and mechanisms that involve the private sector and other stakeholders in tourism management. Traffic and environmental problems can also be added to those. Most of the hotels are located in and around the city center, and the interior of the area lacks accommodation facilities. The hotel prices are expensive and the insufficiency of 2-3 star hotels limits the use of accommodation facilities for those participating in domestic tourism. Traffic problems affect tourist attitude pertaining to travel within the region negatively. Due to the low number of vocational high schools that prepare tourism staff and lack of internship in high schools, there is a shortage of staff for tourism businesses. Despite the fact that some activities related to the promotion have been carried out in recent years, it is not sufficient to introduce the tourism potential of the country. Besides, although there are wide opportunities for the development of health tourism, resources are not utilized sufficiently. There are a number of serious problems with the infrastructure and use of beaches and only by taking effective measures the development of beach tourism can be achieved. In the Khizı district, located in the northern part of Absheron region, the possibilities of developing nature tourism are wide, but the aforementioned potential is not adequately used. For example, incentive policies (e.g., tax incentives) can be implemented in the domestic tourism companies and hotels which will enable to attract more tourists from the target countries. If such policies can be successfully executed, the 
income level of a country's tourism basket will be upgraded and the host country will be able to experience more solid economic performance and will be exposed to lower environmental pollution from the tourist inflows.

Another problem concerns tourism statistics. In order for the internal tourism statistics to be more reliable, additional measures must be taken. Thus, the following measures can be beneficial to solve the tourism problems of Absheron:

- During peak season, the number of tourist visits that exceed the capacity of the regions should be taken under control.

- Measures should be taken for the wider use of medical resources in the region.

- The number of agencies operating in the field of tourism should be increased, and high quality personnel problems should be solved.

- Measures should be taken to raise awareness of the local people about the importance of tourism.

- Ecotourism should be promoted in the region.

- Low interest and long-term loans should be given to businessmen operating in the field of tourism.

- Foreign investments in regional tourism should be stimulated.

- Measures should be taken to ensure that citizens of the country can benefit from reasonable quality tourism services with lower prices.

- Youth tourism should be encouraged and tourism camps should be added suitable equipment for young people.

- Internship opportunities should be expanded for students of tourism schools from developed countries.

- Advertising and publicity works on the tourism area should be expanded, and publication and distribution of quality tourism brochures should be organized.

- Long-term strategies and policies focused on promoting quality employment and job creation, skills development, entrepreneurship, innovation, effective investment, and integrated regional development, are integral to achieving sustainable and inclusive tourism growth - growth that takes into account current and future economic, social and environmental impacts, and addresses the needs of visitors, the industry, the environment and host communities.

- Practices of developed countries should be evaluated in order to develop tourism in the region on similar lines.

- If the above mentioned things are applied, it may be possible to transform the region first into one of the developed tourism centers of the world.

\section{Conclusions and Suggestions}

Today the Absheron Peninsula (Baku - Azerbaijan) is an excellent tourist center on a global scale. With increasing globalization and opportunities around the world, most countries are initiating several policies to reach their targets of economic growth, and tourism has become one of the most significant tools for achieving this aim. This argument is consistent with a number of empirical studies, which document that the tourism sector plays an essential role in promoting economic development across the developed and developing economies around the world. There are great opportunities for health tourism in the region, and government agencies are doing a lot of work in order to increase the number of guests. Data econometric analysis of tourist demand empowers both public and private bodies to make sound economic decisions that can support sustainable and inclusive growth and provide the comparative evidence to analyze the impacts. As a result, governments across the world are able to be more strategically planned and develop more effective policies, enhance their decision-making relating to investment, and further cooperate with the private sector to ensure the tourism sector provides the greatest opportunities for societies to prosper.

\section{References}

Abdullayev, A. D. (2019). Current State and Perspective Development Trends of Health Tourism in the Republic of Azerbaijan. In Advances in Science and Technology, (pp. 154-156).

Abdullayev, F. (2011). Great opportunities for the development of health tourism in our country is available. Gazette of Civilizations. Retrieved from http://medeniyyet.az/page/news/6191/---Olkemizde-mualice-turizminin-inkisafi-ucun-boyuk-potensial-var.html

Ahmadov Fariz, \& Mammadov Egypt. (2015). Strategy of Determining the Competitiveness of Tourism Sector In Azerbaijan And Situation Analysis. 2nd International Congress of Tourism and Management Researches Proceeding Book 01-03 May 2015 Kusadasi - Turkey.

Akbulaev, N., \& Mirzayeva, G. (2020). Analysis of a paired regression model of the impact of income from international tourism on the foreign trade balance. African Journal of Hospitality, Tourism and Leisure, 9(1), Article XX. 
Anselin, L. (2013). Spatial Econometrics: Methods and Models (Vol. 4). Cham, Switzerland: Springer Science \& Business Media. Advanced Studies in Theoretical and Applied Econometrics, 46.

Anselin, L., Gallo, J. L., \& Jayet, H. (2008). Spatial Panel Econometrics. In Mátyás, L., \& Sevestre, P. (Eds.), The Econometrics of Panel Data (pp. 625-660).

Athanasopoulos, G., Song, H., \& Sun, J. A. (2017). Bagging in Tourism Demand Modeling and Forecasting. Journal of Travel Research, 57(1), 52-68.

Azerbaijan Tourism Ministry Introduction Brochure. (2020). Retrieved January 2, 2020, from www.mct.gov.az

Balayev, A. (2019). The scope of services in the global economy: Trends of development. World Economy and International Relations, 6, 23-29.

Donskova, L. I. (2018). Complex approach to personnel management and its stimulation in service activities. Management in Russia and Abroad, 15, 119-124.

Gandilova, S. T. K. (2018). Tourısm and economic development: Analysis and assessment of linkages. Economic Annals-XXI., 174(11-12), 29-33.

Gulyaev, V. G., \& Selivanov, I. A. (2008). Tourism: economics, management, sustainable development: a textbook. M: Soviet Sport, 280. Retrieved October 11, 2018, from http://eco.gov.az/az/151-servetlerimiz

Gulyaev, V. G., Rassokhina, T. V., \& Golodyaeva, V. I. (2016). Scientific Approaches to the development of tourism in the Russian Federation under the conditions of crisis, sanctions and geopolitical instability. Vestnik RMAT, 2, $119-124$.

Huseynov, T. B. et al.. (2003). The Economic and Social Geography of the Republic of Azerbaijan. Baku, ASEU.

Kruzhalin, V. I. (2009). Public-private partnership and the formation of tourist and recreational clusters. Bulletin of the National Academy of Tourism, 2.

Malkina, M. Yu. (2015). Microeconomics. Workshop: Tutorial, M. Yu. Malkina. - Moscow: Infra-M, 60.

Mammedov, J. A., Sultanova, M. V., \& Rahimov, S. N. (2002). International tourism Geography. Baku. "Murersim" Published.

Mirzayeva, G., Turkay, O., Akbulaev, N., \& Ahmadov, F. (2020). The impact of mega-events on urban sustainable development. Entrepreneurship and Sustainability Issues, 7(3), 1653-1666.

Mirzoeva, A., \& Mirzoeva, F. (2016). The main directions and perspectives of the development of tourism in Azerbaijan. International Journal of Humanities and Natural Sciences, 7(1).

Rassokhina, T. V., Sokolov, A. S., Man'ko, N. P., \& Zaitsevsky, I. V. (2015). The main directions of the implementation of investment projects of tourist and recreational clusters. Bulletin of the Russian Academy of Natural Sciences, 15(6), 112-119.

Rosstat [Electronic resource]. Retrieved February 2, 2020, from https://www.gks.rufree

Salihova, S., \& Akbulaev, N. (2015). The Effect of Tourism Sector on the Economic Growth of Kazakhstan: Var Analysis Approach. TURAN: Stratejik Arastirmalar Merkezi, 7(28), 84.

Seryakov, S. G. (2017). Microeconomics: Uch, S. G. Seryakov. - Moscow: Magister, p. 350.

Soltanova, H. (2015) Azerbaycan Cumhuriyetinde Turizm ve Gelişimi, “AZ-TU” Yayınevi, Bakü.

The concept of development "Azerbaijan 2020: vision into the future." Retrieved February 2, 2020, from http://www.President.az/files/future_ru/

The main factors of tourism development. Retrieved February 2, 2020, from http://tourfaq.net/travel-bissnes/glavnye-faktory-vliyayshhie-na-razvitie-turizma/

The Ministry of Mediterranean Waters, the Azerbaijani Republic, Retrieved from https://slideplayer.com/slide/10282484/

Tourism in Azerbaijan. Retrieved February 2, 2020, from http://azerbaigan.tourism.az/ru/peges/17

Turkish stamp on the hundred billion dollar project. Retrieved September 3, 2o14, from http://www.hurriyet.com.tr/ekonomi/27132314.asp

Tuvatova, V. E. (2008). Improving the effectiveness of marketing activities in the hotel business. Marketing in Russia and Abroad, 1, 92-98.

Yulgushev, R. M. (2018). On a systematic approach to the analysis of the development of the hotel complex. Questions of Statistics, 1, 88-89. 